\title{
Research on Occupational Injury Protection System for New Business Practitioners
}

\author{
Lin $\mathrm{Li}^{1}{ }^{1}$, Kecheng Yang ${ }^{1}$ \\ ${ }^{1}$ School of Management, Hebei University, Baoding, China \\ *Corresponding author: Lin Li (Email: 445287525@qq.com)
}

\begin{abstract}
This paper analyzes the necessity of establishing the occupational injury security system for new forms of business and summarizes the pilot areas of the current occupational injury security sy stem, and then analyzes the problems existing in the current occupational injury security for new forms of business, including the difficulty in identifying labor relations and the mismatch between supply and demand of occupational injury security. Finally, the specific conception of occupational injury protection system for employees in the new form of business is put forward, including open insured objects, appropriate payment base, flexible identification of occupational injury, etc.
\end{abstract}

Keywords: Practitioners in new formats, Occupational injury, Occupation al injury protection system.

\section{Introduction}

With the continuous reform of Internet technology and the vigorous development of the digital economy, sharing economy and platform economy, a large number of new business employees who rely on Internet platforms have emerged. Due to their flexible employment characteristics and the complexity of labor relations, they cannot participate in the current work related injury insurance, but their occupational risks are high and work related accidents occur frequently. Therefore, it is necessary to establish an occupational injury protection system for new business employees, improve the work related injury insurance system, and strive to achieve full coverage of work related injury insurance, so as to build a multi-level work-related injury insurance system in China.

\section{Necessity Analysis of Occupational Injury Protection System for New Business Practitioners}

\subsection{Changes in Employment Methods and Risk-taking Methods}

With the continuous reform of Internet technology and the vigorous development of the platform economy, a large number of new business operators who rely on the platform have emerged. The new business enterprises that build Internet platforms have changed the traditional employment methods, and the employment methods of workers have also changed accordingly. This change is mainly manifested in two aspects. First, from the perspective of organizational structure, the traditional two-party relationship has been transformed into a tripartite relationship. The traditional employment method is the "enterprise and employee", which belongs to the relationship between employment and employment. Employers and employees are directly contacted. The employment of new business enterprises is through the construction of a platform. Workers connect through the platform, and the buyers and sellers of their labor or laborers establish contact. The platform is just a bridge, and there has been a flat Relations between Taiwan, buyers and sellers.
Secondly, from the perspective of organizational form, the previous close relationship has changed to a flexible relationship. In the traditional employment method, employees sign fixed labor contracts with enterprises and accept strict management by enterprises. In new business enterprises, the labor relations between the two sides show a loose state, and new business employees can select working hours. Therefore, the employment mode under the new business enterprise has long broken through the traditional employment category, changing from the highly organized employment mode in the past to the flexible employment mode.

The change of employment methods in new business enterprises has also led to changes in the occupational risks of workers. In the past, the risk points were mainly concentrated in the workplace, and the risk points were relatively concentrated, while new business employees mainly relied on Internet platforms for employment. Their working methods were flexible and diverse, their working hours and workplace were uncertain, and occupational risks. The scope and type are different from the occupational risks under traditional employment. At the same time, the way risks are taken has also changed, from employers to new business practitioners themselves. Once there is an industrial accident, they will face the dilemma of defending their rights.

With the development of the economy and society, the employment mode of new business enterprises has changed, and occupational risks have been passed on to new business employees. Therefore, as an industrial injury insurance system with occupational risk as the subject of insurance, its purpose is to provide reasonable occupational injury protection for workers, which determines that the work related injury insurance system must be adjusted in due course with the change of occupational risk range.

\subsection{It Is Difficult for New Business Practitioners to Participate in Work- Related Injury Insurance}

The main difficulties for new business employees to participate in work related injury insurance are mainly institutional barriers. First, the "loopholes" in the work related injury insurance system. Flexible employment is not the 
product of the rise of the platform economy. It has existed for a long time before, but there is no occupational injury guarantee for people without labor relations in flexible employment. According to the provisions of the Social Insurance Law, individual industrial and commercial households without employees, part time practitioners and other flexible employees can participate in basic endowment insurance for employees and basic medical insurance for employees. It is not stipulated that this group can participate in work related injury insurance. Since then, the "Several Provisions on the Implementation of the Social Insurance Law of the People\&apos;s Republic of China" of the Ministry of Human Resources and Social Security has made it clear that part time practitioners can participate in work related injury insurance according to their working hours, leaving individual industrial and commercial households and flexible employment personnel without employees. New business employees belong to flexible employment personnel, that is, the work related injury insurance system has left the group of new business practice employees.

Second, labor relations are complex. Different from the traditional labor relationship, the labor relationship under the new business form is relatively complicated. Judging from the labor characteristics of new business employees, it exists in a form of flexible employment, such as part time, temporary, seasonal, flexible work, etc. And there is a trend of de employment and de organization. The employment relationship, working hours, work content, etc. of new business operators are not fixed. In addition, the income obtained is not obtained from the Internet platform provided by the new business enterprise, but from a third party through the Internet platform. Therefore, the new business enterprise In most cases, the existence of a traditional employment relationship between the two parties is not recognized. In fact, there is a "non labour relationship" or self employment relationship between new business practitioners and platforms. Non labour relations are neither pure employment relations nor labor relations, mainly different from labor relations. However, according to the Regulations on Work related Injury Insurance, having a clear labor relationship is the prerequisite for participating in work related injury insurance. The employer pays the fee, and the individual does not pay. Therefore, due to the complex labor relations of new business employees, it is impossible to determine the payment subject, applicant and responsibility subject of work related injury insurance, and cannot be included in the current work related injury insurance system to protect it.

In a word, the form of employment for new business employees is a flexible, flexible or self employment form. The labor relationship is complex, there is no labor relationship in the legal sense, and there is a lack of a clear payment subject. This means that new business employees are not the object of work related injury insurance system.

\section{Pilot Implementation of Occupational Injury Protection for Employees in New Formats}

\subsection{Some Regions Have Issued Pilot Policies for Occupational Injury Protection}

Paying attention to the occupational injury of flexible employees and protecting their legitimate rights and interests is an important direction in social security work. As early as 2006, Jiangsu Nantong, Taicang, Shandong Weifang and other places have issued a series of policy documents for flexible employment personnel, exploring and establishing occupational injury protection methods for flexible employment personnel and making beneficial attempts. Since then, the "Opinions of the State Council on Doing a Good Job in Employment and Entrepreneurship in the Present and Future Periods" (Guo Fa [2017] No. 28) issued in 2017 proposed to "explore ways to ensure work related injury insurance for flexible employment personnel". " Opinions of the Central Committee of the Communist Party of China and the State Council on Doing a Good Job in the Field of "Agriculture, Rural Areas and Peasants" to Ensure a well off society in an All round Way on time (Decision No. 1 of the Central Committee of the Communist Party of China and the State Council on Accelerating the Improvement of the Socialist Market Economic System in the New Era" (issued on May 11, 2020) clearly put forward Pilot occupational injury protection for employees in new formats should be carried out. At present, Jiujiang City, Jiangsu Province, Shandong Province, Quzhou City, Huzhou City, Jinhua City, Yiwu City and Dongyang City, Chengdu City, Sichuan Province and Guangdong Province have carried out pilot occupational injury protection projects in China (Table 1).

\subsection{Different Regions Have Formed Differentiated Occupational Injury Protection Models}

With the rapid development of new formats, the number of employees engaged in express delivery, takeaway and other new formats has also increased rapidly. Due to the characteristics of flexible employment, there are frequent accidents and injuries. Therefore, their occupational injury protection has continuously become a topic of social concern. In order to meet their occupational injury protection needs, three protection models have been created in different regions according to local conditions, namely, directly incorporating the work related injury insurance model, establishing the occupational injury insurance model and the "1+1" model, that is, the single insurance work related injury insurance plus supplementary commercial insurance model (Table 2). 
Table 1. Situation in each implementation area

\begin{tabular}{|c|c|c|c|}
\hline $\begin{array}{c}\text { Implementation } \\
\text { time }\end{array}$ & $\begin{array}{c}\text { Implementation } \\
\text { area }\end{array}$ & Policy document & Basic content \\
\hline 2006 & Nantong, Jiangsu & $\begin{array}{l}\text { Notice on the Participation of Flexible } \\
\text { Employment Personnel in Work related } \\
\text { Injury Insurance (2006) } \\
\text { Notice on Amending the Notice on the } \\
\text { Participation of Flexible Employment } \\
\text { Personnel in work related Injury Insurance } \\
\text { (2013) }\end{array}$ & $\begin{array}{l}\text { The methods for identifying work related injuries of flexible } \\
\text { employees are clarified, and then the scope of application, } \\
\text { work related injury insurance rates, work related injury } \\
\text { identification, identification and payment of benefits have } \\
\text { been revised. }\end{array}$ \\
\hline 2009 & Weifang, Shandong & $\begin{array}{l}\text { Notice on the Participation of Flexible } \\
\text { Employment Personnel in work related } \\
\text { Injury Insurance (2009) }\end{array}$ & $\begin{array}{l}\text { It is basically implemented with reference to the work- } \\
\text { related Injury Insurance Regulations. }\end{array}$ \\
\hline 2010 & Taicang, Jiangsu & $\begin{array}{l}\text { Implementation Opinions on the } \\
\text { Implementation of Work related Injury } \\
\text { Insurance for Flexible Employment } \\
\text { Personnel (Trial) (2010) } \\
\text { Interim Measures for Occupational Injury } \\
\text { Insurance for Flexible Employees in Taicang } \\
\text { City (2014) } \\
\end{array}$ & $\begin{array}{l}\text { The scope of participation is limited to local household } \\
\text { registration; the work related injury insurance premium is } \\
\text { fully subsidized, and individuals do not bear the payment; } \\
\text { the compensation items and the guarantee level are suitable } \\
\text { for the financing level; the treatment items are insured with } \\
\text { "injury" but not "death". }\end{array}$ \\
\hline 2018 & $\begin{array}{l}\text { Wujiang District, } \\
\text { Suzhou, Jiangsu }\end{array}$ & $\begin{array}{l}\text { Measures for Occupational Injury Insurance } \\
\text { for Flexible Employees in Wujiang District } \\
\text { (Trial) (2018) } \\
\text { Detailed Rules for the Implementation of } \\
\text { Occupational Injury Insurance for Flexible } \\
\text { Employment Personnel in Wujiang District } \\
\text { (2018) }\end{array}$ & $\begin{array}{l}\text { Occupational injury insurance stipulates the scope of } \\
\text { participation, payment standards and insurance benefits, } \\
\text { which are purchased by the government and entrusted to } \\
\text { commercial insurance companies. }\end{array}$ \\
\hline 2019 & Jiujiang, Jiangxi & $\begin{array}{l}\text { Measures for Occupational Injury Insurance } \\
\text { for Flexible Employees in Jiujiang City } \\
\qquad(2019)\end{array}$ & $\begin{array}{l}\text { It stipulates the identification of work related injuries, } \\
\text { entitlements, and rights and obligations. Among them, the } \\
\text { innovative measure is to extend the coverage to all } \\
\text { employees outside work related injury insurance. }\end{array}$ \\
\hline 2019 & Quzhou, Zhejiang & $\begin{array}{c}\text { Guiding Opinions on Optimizing the } \\
\text { Employment of New Business Formats } \\
\text { (2019) } \\
\text { Trial Measures for the Protection of } \\
\text { Occupational Injury for New Business } \\
\text { Practitioners (2020) }\end{array}$ & $\begin{array}{l}\text { It mainly includes adopting flexible and diverse labor } \\
\text { employment methods, deepening the reform of the special } \\
\text { working hours system, building a multi level social } \\
\text { insurance system, and establishing and improving the } \\
\text { management system of new forms of labor employment.It } \\
\text { stipulates the scope and object of occupational injury } \\
\text { protection, insurance procedures and fund raising, work } \\
\text { related injury identification and treatment, and } \\
\text { supplementary commercial insurance. }\end{array}$ \\
\hline 2019 & Chengdu, Sichuan & $\begin{array}{l}\text { Opinions on the Trial Implementation of } \\
\text { Promoting the Participation of Employees in } \\
\text { New Economy and New Business Formats } \\
\text { in Social Insurance (2019) }\end{array}$ & $\begin{array}{l}\text { It mainly deploys new business practitioners to participate } \\
\text { in social insurance tasks and job security. }\end{array}$ \\
\hline 2020 & Huzhou, Zhejiang & $\begin{array}{c}\text { Notice on Trial Measures for the Protection } \\
\text { of Occupational Injury for Employees in } \\
\text { New Businesses such as Express Delivery } \\
\text { Enterprises (2020) }\end{array}$ & $\begin{array}{l}\text { The pilot goal, pilot scope, payment standard, insurance } \\
\text { payment process, identification investigation and } \\
\text { responsibility attribution method, and treatment standard are } \\
\text { proposed. }\end{array}$ \\
\hline 2020 & $\begin{array}{l}\text { Jinhua, Yiwu, } \\
\text { Zhejiang }\end{array}$ & $\begin{array}{l}\text { Guiding Opinions on Carrying out Pilot } \\
\text { Occupational Injury Protection for New } \\
\text { Business Practitioners (2020) } \\
\text { Implementation Opinions of Jinhua } \\
\text { Takeaway Practitioners Participating in } \\
\text { Work-related Injury Insurance }(2020) \\
\end{array}$ & $\begin{array}{l}\text { Identify Jinhua City and Yiwu City as pilot areas; formulate } \\
\text { a "1+N" policy system to achieve full coverage by the end } \\
\text { of } 2020 \text {, and achieve full coverage of participation and } \\
\text { protection of treatment by the end of } 2022 \text {. }\end{array}$ \\
\hline 2020 & Dongyang, Zhejiang & $\begin{array}{l}\text { Notice of the Reform Commission of } \\
\text { Dongyang Municipal Party Committee on } \\
\text { Printing and Distributing the Interim } \\
\text { Measures for Mass Actors to Participate in } \\
\text { work related Injury Insurance (Trial) (2020) }\end{array}$ & The scope of coverage has been expanded to extras. \\
\hline 2021 & $\begin{array}{l}\text { Guangdong } \\
\text { Province }\end{array}$ & $\begin{array}{l}\text { Measures on work related Injury Insurance } \\
\text { for Workers Over the Legal Retirement Age } \\
\text { and Other Specific Personnel practising in } \\
\text { Units (Trial) (2020) }\end{array}$ & $\begin{array}{l}\text { It includes the background of the policy, the scope of } \\
\text { insured objects, the principle of voluntary participation, the } \\
\text { handling method of work related injury insurance, payment } \\
\text { standards, and treatment standards. }\end{array}$ \\
\hline
\end{tabular}


Table 2. Comparison of different modes

\begin{tabular}{|c|c|c|c|}
\hline & $\begin{array}{l}\text { Directly included in work related injury } \\
\text { insurance }\end{array}$ & Establish occupational injury insurance & "1+1" mode \\
\hline Pilot area & $\begin{array}{c}\text { Weifang City, Shandong Province, Chengdu City, } \\
\text { Sichuan Province, Jinhua City, Yiwu City, } \\
\text { Dongyang City and Guangdong Province }\end{array}$ & $\begin{array}{l}\text { Nantong City, Taicang City, Wujiang District, } \\
\text { Suzhou City and Jiujiang City, Jiangxi Province }\end{array}$ & Quzhou and Huzhou, Zhejiang \\
\hline $\begin{array}{c}\text { Insured } \\
\text { object }\end{array}$ & $\begin{array}{c}\text { (1) Weifang City, Shandong Province is a variety } \\
\text { of flexible employees, especially construction } \\
\text { enterprises. } \\
\text { (2) Jinhua City, Zhejiang Province is a takeaway } \\
\text { person who does not participate in work related } \\
\text { injury insurance } \\
\text { (3) Yiwu promotes takeaway and express } \\
\text { delivery practitioners to participate in insurance } \\
\text { (4) Dongyang is mainly a film and television } \\
\text { extra } \\
\text { (5) Guangdong Province includes online car } \\
\text { hailing, takeaway, express labor and other new } \\
\text { business formats }\end{array}$ & $\begin{array}{l}\text { (1) Nantong City and Taicang City, Jiangsu } \\
\text { Province cannot participate in the insurance } \\
\text { alone, provided that flexible employees who } \\
\text { participate in endowment insurance or medical } \\
\text { insurance } \\
\text { (2) Flexible employment personnel of Wujiang } \\
\text { District, Suzhou City as a local and foreigner } \\
\text { (3) Jiujiang City, Jiangxi Province includes } \\
\text { flexible employees who are not included in work } \\
\text { related injury insurance }\end{array}$ & $\begin{array}{l}\text { Quzhou City and Huzhou City } \\
\text { are new takeaway and express } \\
\text { delivery practitioners. }\end{array}$ \\
\hline $\begin{array}{l}\text { Payment } \\
\text { standard }\end{array}$ & $\begin{array}{l}\text { (1) The payment rate in Weifang City, Shandong } \\
\text { Province is charged according to the benchmark } \\
\text { rate of category II industry (1\%). The work } \\
\text { related injury premium is the monthly payment } \\
\text { base of social insurance premium for insured } \\
\text { personnel } \times 1 \% \text {, and construction enterprises pay } \\
\text { a certain proportion of the total project cost. } \\
\text { (2) The payment base of Jinhua City, Zhejiang } \\
\text { Province is the average monthly salary of } \\
\text { employees in Zhejiang Province in the previous } \\
\text { year, and the benchmark rate is set at } 0.4 \% \\
\text { according to the second category. However, the } \\
\text { rate will fluctuate up and down according to the } \\
\text { previous compensation situation of new business } \\
\text { enterprises and the probability of work-related } \\
\text { injuries. } \\
\text { (3) The payment base of Dongyang City is } 11 \% \\
\text { of the crew\&apos;s income. } \\
\text { (4) The payment rate of Guangdong Province } \\
\text { shall be implemented in accordance with the } \\
\text { provisions of the industry benchmark rate and } \\
\text { floating rate. }\end{array}$ & $\begin{array}{l}\text { (1) The insurance rate in Nantong City, Jiangsu } \\
\text { Province is tentatively set at } 0.5 \% \\
\text { (2) Taicang City, Jiangsu Province shall raise } \\
\text { funds according to the total amount of } \\
\text { contributions not exceeding } 1 \% \text { of the minimum } \\
\text { social insurance payment base per person in the } \\
\text { current year. } \\
\text { (3) The occupational insurance premium in } \\
\text { Wujiang District, Suzhou City is tentatively set at } \\
180 \text { yuan per person per year, and the financial } \\
\text { subsidy is } 120 \text { yuan per person per year. } \\
\text { (4) The payment standard of occupational injury } \\
\text { insurance in Jiujiang City, Jiangxi Province is } \\
\text { tentatively set at } 180 \text { yuan per person per year, } \\
\text { once a year. }\end{array}$ & $\begin{array}{l}\text { (1) New business enterprises in } \\
\text { Quzhou City, Zhejiang } \\
\text { Province pay work related } \\
\text { injury insurance premiums on a } \\
\text { monthly basis based on the } \\
\text { average monthly salary of } \\
\text { employees in the province in } \\
\text { the previous year, and refer to } \\
\text { the benchmark rate of the } \\
\text { second class industry in the } \\
\text { postal industry, and implement } \\
\text { floating rates. } \\
\text { (2) The benchmark rate of } \\
\text { occupational injury protection } \\
\text { in Huzhou City, Zhejiang } \\
\text { Province refers to the second } \\
\text { grade (0.4\%) of the industry } \\
\text { classification postal industry } \\
\text { (express service) and catering } \\
\text { industry (categoing and } \\
\text { distribution service). Only } \\
\text { 22.14 yuan is paid for each } \\
\text { employee per month. }\end{array}$ \\
\hline $\begin{array}{l}\text { Insurance } \\
\text { payment }\end{array}$ & $\begin{array}{l}\text { (1) Work related injury insurance premiums in } \\
\text { Weifang City, Shandong Province are paid } \\
\text { simultaneously with employees\&apos; basic } \\
\text { endowment insurance premiums and basic } \\
\text { medical insurance premiums } \\
\text { (2) New business enterprises in Jinhua City, } \\
\text { Zhejiang Province declare to the local social } \\
\text { security institutions the number of insured in the } \\
\text { current year, participate in work related injury } \\
\text { insurance and supplementary work related injury } \\
\text { insurance in accordance with the insurance } \\
\text { management method of "total total dry, dynamic } \\
\text { real name", and pay off the relevant insurance } \\
\text { premiums for one cycle at one time. } \\
\text { (3) Dongyang City, Zhejiang Province, with film } \\
\text { and television enterprises as the unit, will apply } \\
\text { to the social security center for work related } \\
\text { injury insurance. } \\
\text { (4) Guangdong practitioners can apply for } \\
\text { individual work related injury insurance for } \\
\text { employees. }\end{array}$ & $\begin{array}{l}\text { (1) Nantong City, Jiangsu Province includes } \\
\text { occupational injury insurance funds in work } \\
\text { related injury insurance funds } \\
\text { (2) Taicang City, Jiangsu Province, is included in } \\
\text { occupational injury insurance and a special } \\
\text { financial account for occupational injury } \\
\text { insurance funds is established. } \\
\text { (3) Wujiang District, Suzhou City learns from the } \\
\text { handling mode of serious illness insurance and } \\
\text { adopts the model led by the government and } \\
\text { undertaken by Shengye Insurance Company. }\end{array}$ & $\begin{array}{l}\text { Zhejiang New Business } \\
\text { Enterprises shall declare the } \\
\text { insured personnel to the local } \\
\text { social security institutions, } \\
\text { submit the "Increase and } \\
\text { Decrease of Social Insurance } \\
\text { Employees (Employment } \\
\text { Registration) Form" and other } \\
\text { materials. After approval by the } \\
\text { social security institutions, they } \\
\text { shall determine and declare the } \\
\text { approved work related injury } \\
\text { insurance premiums through } \\
\text { the Zhejiang Electronic } \\
\text { Taxation Bureau of the State } \\
\text { Administration of Taxation on } \\
\text { a monthly basis. }\end{array}$ \\
\hline $\begin{array}{l}\text { Identification } \\
\text { of } \\
\text { work-related } \\
\text { injuries }\end{array}$ & $\begin{array}{l}\text { (1) Weifang City, Shandong Province, according } \\
\text { to the relevant provisions of the Regulations on } \\
\text { Work related Injury Insurance, employees in } \\
\text { construction enterprises cannot apply for work } \\
\text { related injury recognition for more than } 30 \text { days } \\
\text { after work-related injuries. } \\
\text { (2) Jinhua City, Zhejiang Province shall } \\
\text { implement the Regulations on Work related } \\
\text { Injury Insurance and Regulations of Zhejiang } \\
\text { Province on Work related Injury Insurance. } \\
\text { Relevant departments carry out work related } \\
\text { injury identification according to the principle of } \\
\text { "three works" }\end{array}$ & $\begin{array}{l}\text { (1) Nantong City, Jiangsu Province only includes } \\
\text { articles XIV (I), (II), (III) and (V) of the } \\
\text { Regulations on Work related Injury Insurance in } \\
\text { the scope of work related injury identification. } \\
\text { (2) The identification of work related injuries in } \\
\text { Taicang City, Jiangsu Province includes four } \\
\text { situations: first, injuries due to work reasons in } \\
\text { the workplace and professional positions; second, } \\
\text { injuries caused by violence and other accidents } \\
\text { due to the performance of work duties; third, } \\
\text { injuries in the protection of national and public } \\
\text { interests such as emergency rescue and disaster } \\
\text { relief; fourth, injuries in the workplace and } \\
\text { occupations Sudden illness on the post is } \\
\text { determined to be completely incapacitated by } \\
\text { labor ability appraisal. }\end{array}$ & $\begin{array}{l}\text { (1) Quzhou City, Zhejiang } \\
\text { Province, gives full play to the } \\
\text { role of the platform as the main } \\
\text { employer, and takes the } \\
\text { dispatch and receiving record } \\
\text { of the platform as an important } \\
\text { basis for determining the } \\
\text { working hours, workplace and } \\
\text { work reasons. If employees } \\
\text { participate in work related } \\
\text { injury insurance in multiple } \\
\text { new business enterprises, the } \\
\text { dispatch enterprise that is } \\
\text { delivering the order at the time } \\
\text { of the accident shall bear the } \\
\text { work related injury. Insurance }\end{array}$ \\
\hline
\end{tabular}




\begin{tabular}{|c|c|c|c|}
\hline & $\begin{array}{l}\text { Directly included in work related injury } \\
\text { insurance }\end{array}$ & Establish occupational injury insurance & "1+1" mode \\
\hline & & $\begin{array}{l}\text { (3) If the insured personnel in Wujiang District, } \\
\text { Suzhou City are injured by a sudden, } \\
\text { unintentional or non disease accident due to work } \\
\text { reasons, resulting in death, disability or injury, } \\
\text { they shall actively file with the insurance agency, } \\
\text { and the labor ability appraisal committee shall } \\
\text { classify the disability level and enjoy different } \\
\text { levels of protection. } \\
\text { (4) Flexible employees under the new economic } \\
\text { and new business formats in Jiujiang City, } \\
\text { Jiangxi Province, are injured by sudden, } \\
\text { unintentional and non disease accidents due to } \\
\text { work reasons in their professional positions. }\end{array}$ & $\begin{array}{l}\text { liability shall be handled in } \\
\text { accordance with the relevant } \\
\text { provisions on the handling of } \\
\text { labor disputes due to disputes } \\
\text { over work related injuries with } \\
\text { new business enterprises.(2) } \\
\text { Huzhou City, Zhejiang } \\
\text { Province shall determine the } \\
\text { relevant responsibilities in } \\
\text { accordance with the } \\
\text { Regulations on work related } \\
\text { Injury Insurance and the } \\
\text { Regulations of Zhejiang } \\
\text { Province on Work related } \\
\text { Injury Insurance. For } \\
\text { employees participating in } \\
\text { multiple new formats of } \\
\text { enterprises, the enterprise that } \\
\text { are dispatching the order shall } \\
\text { be undertaken. If multiple tasks } \\
\text { are dispatched at the same time, } \\
\text { the enterprise with the first } \\
\text { order of the same journey shall } \\
\text { be borne by the enterprise. }\end{array}$ \\
\hline $\begin{array}{l}\text { Treatment } \\
\text { protection }\end{array}$ & $\begin{array}{l}\text { (1) Flexible employment personnel in Weifang } \\
\text { City, Shandong Province in accordance with the } \\
\text { Regulations on Work related Injury Insurance } \\
\text { (2) Employees in Jinhua City, Zhejiang Province } \\
\text { are assessed as level five to ten due to work } \\
\text { related disability. They mainly enjoy one time } \\
\text { work related injury medical subsidies and one } \\
\text { time disability employment subsidies, and enjoy } \\
\text { different standards of one time disability } \\
\text { employment subsidies according to the degree of } \\
\text { disability. } \\
\text { (3) The treatment guarantee in Dongyang City, } \\
\text { Zhejiang Province shall be determined by } 60 \% \\
\text { of the average salary of employees in the } \\
\text { previous year. } \\
\text { (4) The disability allowance and endowment } \\
\text { insurance benefits of employees at levels I to IV } \\
\text { in Guangdong Province shall be handled in } \\
\text { accordance with the principles of "no double } \\
\text { enjoyment" and "no high or bad treatment"; for } \\
\text { employees at levels five to ten due to work } \\
\text { related injuries and disability, one time medical } \\
\text { subsidies for work related injuries can be issued } \\
\text { on the basis of the application, and can continue } \\
\text { to enjoy work related injuries during the } \\
\text { application period. The right to benefits paid by } \\
\text { the insurance fund will terminate its work related } \\
\text { injury insurance relationship after receiving it. }\end{array}$ & $\begin{array}{l}\text { (1) In addition to the responsibilities of the } \\
\text { employer, Nantong City, Jiangsu Province, other } \\
\text { benefits are basically implemented with } \\
\text { reference to the Regulations on work related } \\
\text { Injury Insurance, but all the benefits originally } \\
\text { paid regularly have been changed to one time } \\
\text { payment benefits.(2) Medical expenses in } \\
\text { Taicang City, Jiangsu Province shall be } \\
\text { implemented by the medical insurance fund in } \\
\text { accordance with the relevant provisions of work } \\
\text { related injury insurance; disabled persons at } \\
\text { levels } 1 \text { - } 6 \text { enjoy social insurance subsidies; } \\
\text { disabled persons at levels } 14 \text { enjoy basic living } \\
\text { allowance according to the minimum living } \\
\text { allowance standards for urban and rural } \\
\text { residents, and disabled persons at levels } 510 \\
\text { enjoy one time basic living allowance; injuries } \\
\text { Disabled people enjoy subsidies for installing } \\
\text { assistive devices(3) After the medical expenses in } \\
\text { Wujiang District, Suzhou City are reimbursed by } \\
\text { medical insurance first, the balance shall } \\
\text { continue to be reimbursed within the limit of } 3 \\
\text { million yuan per insured year; the compensation } \\
\text { standard is about } 50 \% \text { of the current work related } \\
\text { injury insurance compensation standard shall be } \\
\text { received in one lump sum medical expenses, } \\
\text { disability allowance, disability allowance and } \\
\text { death allowance.(4) Jiujiang City, Jiangxi } \\
\text { Province, can enjoy the treatment of occupational } \\
\text { injury hospitalization medical expenses, } \\
\text { occupational injury disability allowance, } \\
\text { occupational injury hospitalization allowance, } \\
\text { occupational injury death allowance and other } \\
\text { benefits. Occupational injury death allowance } \\
\text { and occupational injury disability allowance are } \\
\text { not shared. }\end{array}$ & $\begin{array}{l}\text { Those who participate in the } \\
\text { work related injury insurance } \\
\text { policy shall enjoy benefits in } \\
\text { accordance with the relevant } \\
\text { provisions of the work related } \\
\text { injury insurance. If they } \\
\text { participate in supplementary } \\
\text { commercial insurance, the } \\
\text { enterprise and the commercial } \\
\text { insurance company shall jointly } \\
\text { bear the responsibility. }\end{array}$ \\
\hline Undertakers & $\begin{array}{l}\text { New business enterprises, practitioners and } \\
\text { governments }\end{array}$ & Individual, commercial insurance company & $\begin{array}{l}\text { New business enterprises, } \\
\text { government and commercial } \\
\text { insurance companies }\end{array}$ \\
\hline
\end{tabular}

\section{Current Problems in Occupational Injury Protection for New Business Operators}

\subsection{Difficulties in Determining Labor Relations for New Business Employees}

The employment status of employees in new formats is complex, and there are many modes of employment and multi employer employment interaction, including self employment franchise or crowdsourcing orders. Take online car hailing as an example. Practitioners have an employment mode of registering on the platform and joining their own vehicles according to the rules of the platform. There is also an employment mode that uses platform vehicles and abides by the platform's employment regulations. There is a form of part time and full time coexistence. Moreover, employees in new formats are employed across multiple platforms, and multiple employers exist at the same time. For new business employees who are self employed or crowdsourcing orders, because there is neither a written labor contract nor a de facto 
labor relationship between them and the platform, there are no clear standards for their relationship with the platform as "labor relations", "cooperative relations" or "partnership", resulting in It is difficult to identify labor relations among employees in new business formats.

\subsection{Insufficient Supply of Occupational Injury Protection for Employees in New Formats}

The supply of occupational injury protection for employees in new formats mainly comes from two aspects. First, the guarantee at the institutional level, such as the policy documents issued on the pilot implementation of the occupational injury protection system. From the perspective of the whole country, there are only a few provinces, cities and regions to carry out the occupational injury protection system. Although most provinces, cities and regions have a rapid economic development, they are still in a wait and see state due to various factors. Second, commercial insurance purchased on the platform built by various new business enterprises (Table 3). These commercial insurances generally have problems such as high contribution level, narrow coverage, difficult insurance claims and low security level, and there is no long-term treatment payment.

Table 3. Commercial insurance content of some platforms

\begin{tabular}{cc}
\hline Platform name & Commercial insurance content \\
\hline Meituan & $\begin{array}{c}\text { Accidental injury insurance (3 yuan per } \\
\text { day), liability insurance for three } \\
\text { Personal accident insurance, accident } \\
\text { medical insurance and three party liability } \\
\text { insurance. During the insurance period, it is } \\
\text { within 30 minutes after the completion of } \\
\text { meal collection, delivery and order delivery. } \\
\text { "Caring Treasure", "Drip Medical } \\
\text { Insurance" }\end{array}$ \\
Didi & $\begin{array}{c}\text { Property damage insurance, personal } \\
\text { accident insurance }\end{array}$ \\
\hline
\end{tabular}

Data source: questionnaire survey and online relevant information collation

To sum up, combined with the supply and demand for occupational injury protection for new business employees, with the continuous expansion of the scale of the new business practice group, its occupational risks are also increasing, but whether from the institutional level of occupational injury protection or the commercial insurance purchased by the platform under the new business format enterprise Insurance can\&apos; t meet the needs of new business practitioners for occupational injury protection. In addition, due to the uneven economic development of various regions and the large regional differences, there are also obstacles in the country's introduction of a unified occupational injury guarantee system for new business employees.

\section{Countermeasures of Occupational Injury Protection System for New Business Practitioners}

The occupational injury protection system for new business employees is not one size fits all in terms of protection objects, payment bases, insurance forms, security levels, etc. It adopts a multi level security form to expand the coverage group as much as possible. At present, the occupational injury protection system model is in the pilot stage. Each region should fully take into account the local economic development level, and design an institutional model suitable for local needs after investigating the occupational injury protection needs of employees in new formats and inspecting the mature experience of the pilot areas. According to the operation mode of occupational injury protection in the current pilot areas and the relevant content of social insurance, this paper puts forward the following assumptions.

\subsection{Open Insured Objects}

Judging from the participation caliber of the occupational injury protection system in the pilot area, the largest insurance scope is Wujiang District, Suzhou City, Jiangsu Province. There is no household registration. The insurance scope is all flexible employees in the region, while Taicang City, Jiangsu Province, is only for local household registration practitioners, with a small caliber of insurance. From the perspective of the degree of openness to flexible employment personnel, the pilot areas of Zhejiang Province, such as Quzhou City, Huzhou City, Jinhua City, etc., are mainly aimed at new business personnel. Wujiang District, Suzhou City, Weifang City, Shandong Province, etc. guarantee all flexible employment personnel, while Jiujiang City, Jiangxi Province includes all employees who have not participated in work related injury insurance, such as New business practitioners such as laborers without labor relations, retired migrant workers, interns, online contracting personnel, etc. are the most thorough. Therefore, the specific coverage should be in line with the development of the region. In addition, it should be fully taken into account that there is no stable labor relationship for new business employees and poor employment stability.

\subsection{Appropriate Payment Base}

There are two options for determining the payment base. One is based on the salary of employees in new business forms, which can play a role in stimulating the enthusiasm of employees to work. However, because new business employees often register multiple platforms, the income cannot be accurately calculated, and it is difficult to manage. The other is fixed payment, that is, calculate the fixed payment amount in each cycle, and employees in new formats pay according to the standard. This method is convenient for unified management and calculation, but it has less incentive effect on employees.

\subsection{Flexible Identification of Occupational Injuries}

In the traditional employment form, working hours, workplaces and work reasons are easy to determine, and work related injuries are easy to identify. However, the most typical feature of new business practitioners is flexibility, which is more difficult to identify occupational injuries according to the principle of "three industries". The flexible working hours and workplaces of employees in new formats make it difficult to define the specific commuting distance clearly. Therefore, it is necessary to combine the characteristics of flexible employment of new business employees and innovate the method of identifying work related injuries. Judging from the current pilot method of identifying occupational injury, Quzhou takes the basis for judging working hours, workplace and work reasons according to the record of receiving orders and dispatches on the platform. If it appears on multiple 
platforms to participate in insurance, the dispatch platform that is delivering orders at the time of occupational injury will be liable. Huzhou added that if multiple orders are being delivered at the time of occupational injury, and the responsibility of the platform is difficult to determine, the platform that receives orders of the same distance shall be liable. At present, Qingdao is the first in the country in realizing remote reporting of work related injury insurance. Log in and use by downloading the mobile application, upload short videos, photos and other related materials of injuries within 48 hours of the work related accident, and briefly describe the accident. This digital work-related injury identification method is worth referring to.

\subsection{Reasonable Insurance Benefits}

Judging from the policy document on occupational injury protection for new business employees issued in the pilot area, when new business employees encounter occupational injuries and suffer from occupational diseases during the insurance period, they basically refer to the work related injury insurance benefits, which has a strong reference, but about the part of work related injury insurance undertaken by new business enterprises. Liability, some pilot areas pass on the part of the risk they should bear by purchasing commercial insurance, and realize the organic combination of social insurance and commercial insurance in the payment of work related injury insurance benefits. At the same time, according to the characteristics of employees in new formats, we should do a good job in the connection with medical insurance benefits in terms of treatment payment, which can be implemented in accordance with the principles of non double enjoyment and high compensation for low treatment.

\section{Acknowledgment}

Human Resources and Social Security Department of Hebei Province: Research on occupational injury protection policy for flexible employment personnel in the new industry in Hebei Province No.JRSHZ-2021-01033).

\section{References}

[1] Xie Fusheng, Wu Yue. Is the gig economy a win win employment relationship between labor and management $[\mathrm{J}]$. Economist, 2019(06):5-14.

[2] He Wenjiong. Promote fairer, more sustainable and more efficient social security [J]. People's Forum, 2019 (31):37-39.

[3] $\mathrm{Qu}$ Renshe. Analysis of the problem of labor security in new forms of work in Quzhou, hejiang [J]. China Human Resources and Social Security, 2020(10):14-15.

[4] Zhu Xiaoyu. Discussion on the Occupational Injury Protection System for New Business Practitioners: A Study Based on Leading Enterprises in Platform Economy [J]. Journal of Huazhong University of Science and Technology (Social Science Edition), 2021,35(02):32-40.

[5] Weng Renmu. Research on the Occupational Injury Protection System for Platform Employees [J]. China Labor, 2019(10):7890 .

[6] Yuan Ye. Under the background of the new business format, the current situation, influencing factors and countermeasures of social endowment insurance participation of flexible employees [D]. Northwest University, 2019.

[7] Chen Cheng, Sun Hong. Discussion on the Path to Improving the Work related Injury Insurance System: Investigation Practice from Tinghu District, Yancheng City [J]. China Human Resources and Social Security, 2019(04):19-21.

[8] Human resources and social informationization.Enter the new journey of Internet Plus[J]. China Human Resources and Social Security, 2019(10):29-30.

[9] Min Fanxiang. The State and Society: A Study on the Changes of British Social Welfare Concepts and the Social Welfare Reform of Thatcher's Government [M]. Chongqing Publishing, 2009 (03):101-117.

[10] Wang Xianyong, ia Qing. Theoretical basis and institutional concept of online contract workers included in work related injury insurance under the sharing economy platform [J]. China Labor, 2018(06):49-53. 